\title{
K\&KK
}

søger studerende som

kontaktpersoner og selgere

på universitetsinstitutterne

Bl.a. på:

Institut for litteraturvidenskab, KU

Institut for nordisk filologi, $\mathrm{KU}$

Institut for film, TV og kommunikation, $\mathrm{KU}$

Institut for litteraturvidenskab, OU

Nordisk institut, $\mathrm{OU}$

Institut for litteraturhistorie, $\mathrm{AU}$

Nordisk institut, AU

Institut for medie- og informationsvidenskab, AU

Institut for kommunikation, AUC

og på RUC/dansk- og medieuddannelsen

Jobbet er provisionslønnet. Henvendelse til

\section{Forlaget Medusa}

TIf. 02424000

Postboks 1, 2840 Holte 